THE CASA GRANDE RUIN, SOUTHERN ARIZONA.*

By Cosmos MindelefF.

SITUATED near the Gila River, in Southern Arizona, is perhaps the best known specimen of aboriginal architecture in the United States, and no treatise on extended description of it Its literature, which less tends over two centuries, is voluminous, but of little value to the practical scientific worker, since hardly two descriptions can be found which agree. The variations in size of the ruin given by various authors is astonishing, ranging from 1,500 square feet to nearly five acres or about 200,000 square feet in area. These extreme variations are doubtless due to difference of judgment as to what portion of the area covered by remains of Th this structure is but a portion of a large group of ruins.

The earlier writers generally state that the Casa Grande was in ruins at the time of the first Spanish invasion of the country, in 1540, and quote in support of this assertion Castaneda's description of a ruin en countered on the march, Castaneda saying, "The structure was in ruins, and without a roof." Elsewhere he place where they stopped because the monks found in the vicinity a house which had been inhabited by a people who came from Cibola. He surmises that the ruin was formerly a fortress, destroyed long before by the barbarous tribes which they found in the country. His description of these tribes seems to apply to the Apache.

In 1694 the Jesuit Father Kino heard of the ruin, and later in the same year visited it and said mass within edifice, the principal room in the center being four stories high, and those adjoining it on its four sides three stories, with walls two varas thick, of strong avgamaso $\mathrm{y}$ baro (adobe), so smooth on the inside that they resembled planed boards, and so polished that they shine like Puebla pottery." Mange also states

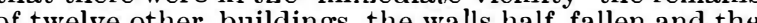
of twelve other buildings, the walls half fallen and the descriptions, among the latest being those of members of the Hemen way sou th western archrological expedition. The ruin is about half a mile from the Gila River, directly on one of the stage routes from Casa Grande station, on the Southern Pacific Railroad, to Florence, Arizona, and about nine miles below or west of the latier place. The name has been usually applied to a of a but some writers have applied it to the southwestern portion of the area and even to the whole area the name Casa Grande ruin being, perhaps, more properly applied to the single structure with standing walls. It occupies a position near the south western corner of the group of ruins; and its size is magnificent as compared with that of the entire group, or even with the large For

For miles about the Casa Grande ruin, a general view surface is so flat in every direction that from the summit of its walls an immense stretch of country is brought into view. The area covered and inclosed by standing walls is about 43 by $59 \mathrm{ft}$. The building comprised three central rooms, each approximately 10 by 24 it., and two other rooms, each about 9 by $35 \mathrm{ft}$. Except the central were two stories above the ground. The northeastern and southeastern corners of the structure have fallen and large blocks of the material of which they were composed are strewn upon the ground in the vicinity It is not likely that the main building originally stood alone, asat present, and the area inmedately ad jacent, now covered by mounds, probably carried buildings * Condensed from an exbaustive paper in the Thirteenth Annual Report
of the Bureau of Ethnology, Washington, D. C., J. W. Powell, Director.

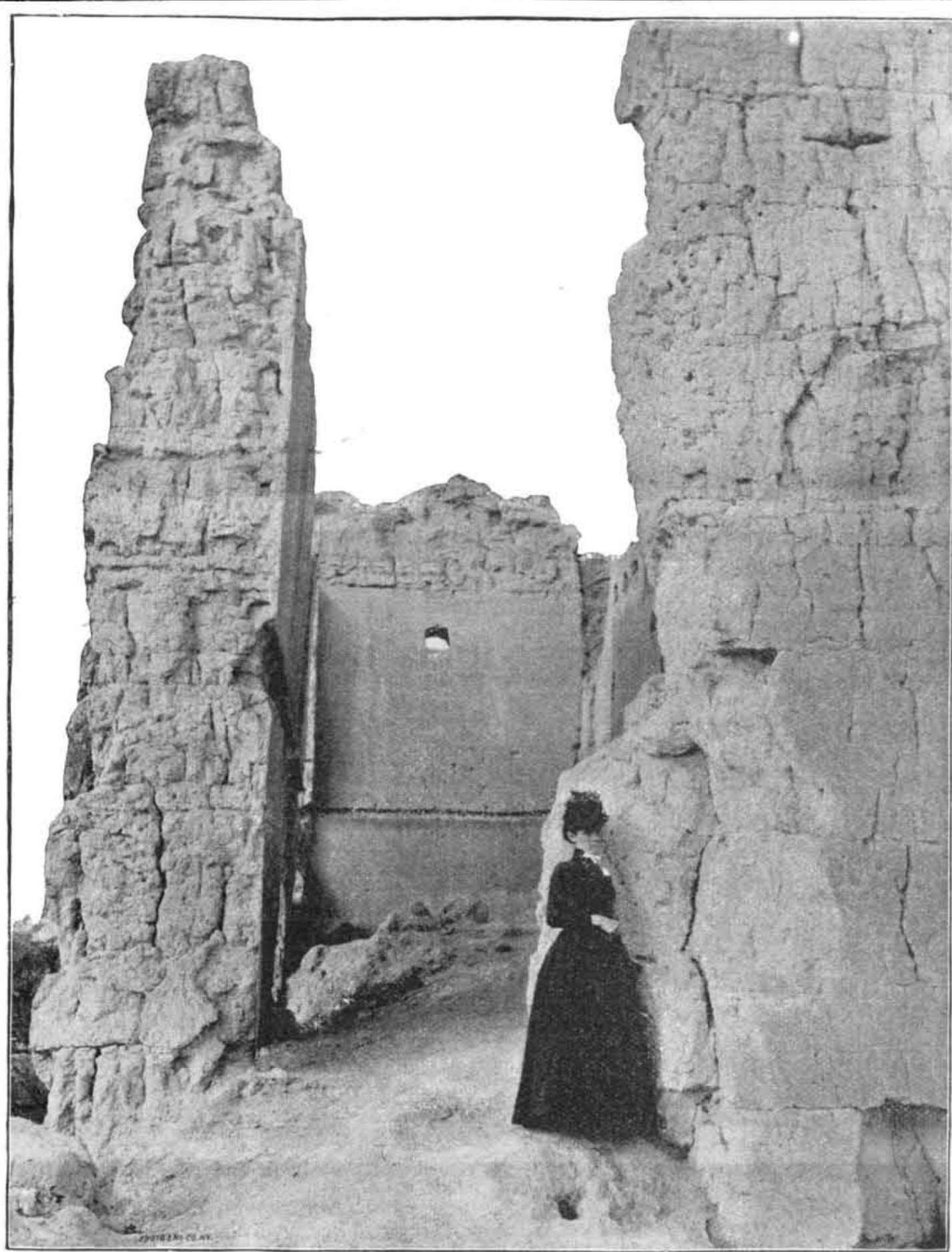

CASA GRANDE RUIN-SQUARE OPENING IN SOUTH ROOM

the same time with the main structure. The ex- thoroughly aboriginal in character, and there is no thior walls rise to a height of 20 to $25 \mathrm{ft}$. above the uniformity in its measurements. The walls, even in the

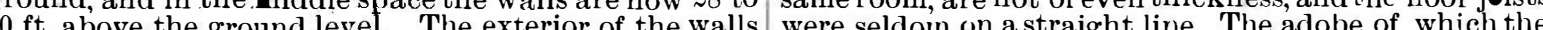
rough, but the interior walls of the rooms are fished with remarkable smoothness, this fine finish being ap- dried in the sun, but the walls are composed of huge arent in the illustration showing a square opening in blocks of clayey earth, probably formed in place in a 5 south room. The walls at the base are from $21 \%$ to box or trough held in a framework of canes or poles. $5 \mathrm{ft}$. thick, and at the top are reduced to about $2 \mathrm{ft}$. The material, when dry, became almost as hard a The building was constructed by crude methods, sandstone, and practically indestructible, in the clim

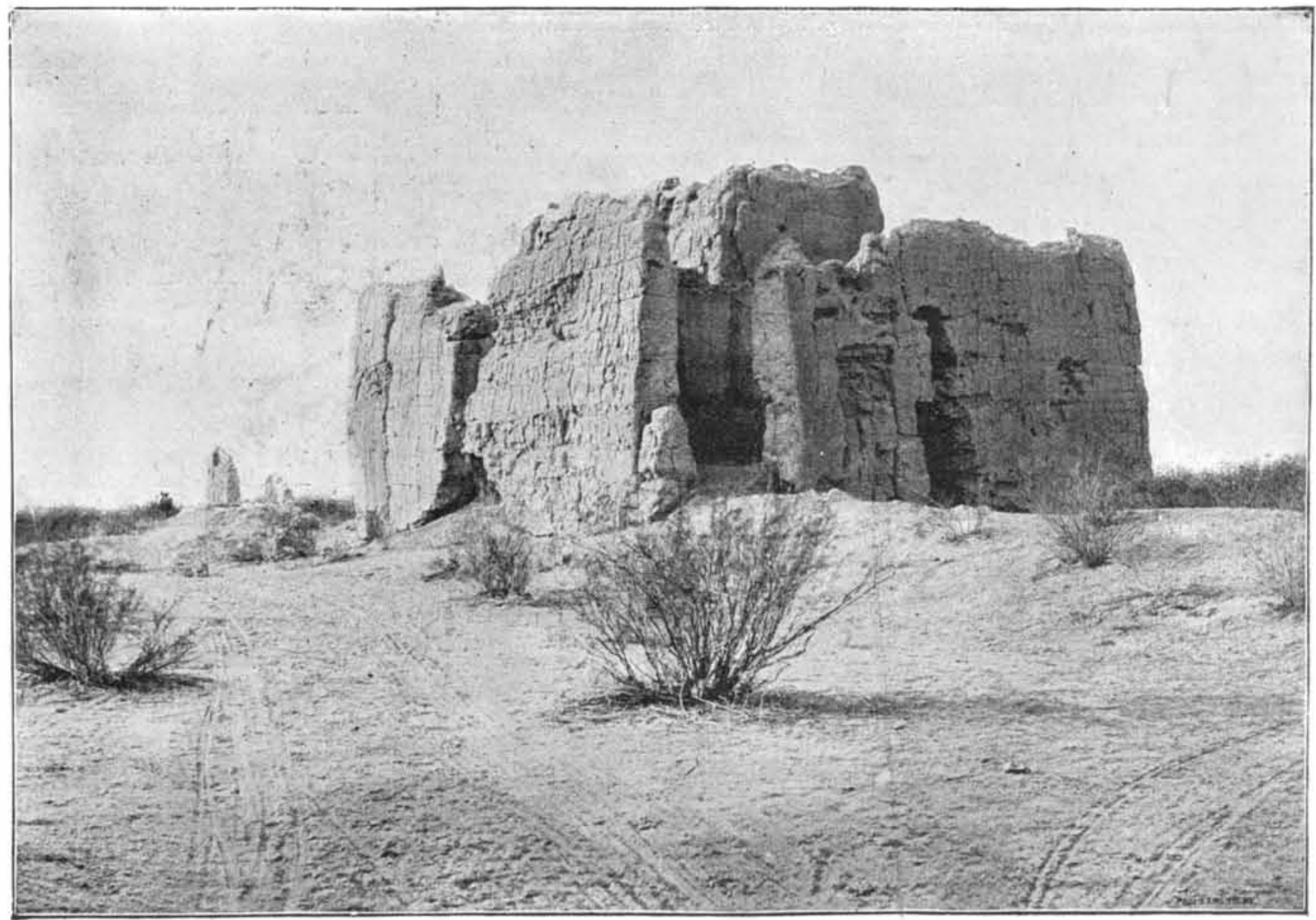

GENERAL VIEW OF CASA GRANDE RUNN. 
ate of the region. The damage done by relic hunters in the last twenty years has been probably much greater than that wrought by the elements in the preceding two aenturies. The writer has been reliably the floor or roof in one of the roons was still in place, cept marks on the vertical walls, and a few stumps of floor joists, deeply embed from the grouns

FLUID AIR FOR INDUSTRIAL USES.* IMQUEFYING air is not a new thing; it has been performed by excrting enormous pressure or by freezing sure with refrigeration. There are so many uses to know where its usefulness will end if it can be produced new method and machine has accomplished.

Among other advantages, air in the portable, cheap form of a liquid, as it passes back to its ordinary stat can be used for illuminating purposes by mixing its
escaping gases with atmospheric aîr in certain definite proportions. Moreover, as a driving force in the way liquid air is obviously a power that can be, under given conditions, profitably applied.

Hitherto the classic example of a method to liquef air and obtain oxygen has been that invented by Beatty and Cailletet in 1877. With their machine, one be gas was condensed in a tube, round which lay water at $10^{\circ}$ to keep the tube cool. The carbonic acid gas, be first tube into anerylow temper with passed from the in so doing fell to a lower temperature. Into this secoud tube was pumped at high pressure eth ylene gas, which in turn fell to a low temperature, owing to the coldness
of the carbonic acid gas bathing the tube. The ethylene gas was then passed from the second tube into so doing. The third compartment had likewise a tube with an air pump attacher. Into this third tube pumped oxygen gas and from the ethylene gas bathing it the oxygen gas reached a temperature of $192^{\circ}$ below
zero. Finally, the oxygen was let out into a fourth compartment, in which was a fourth tube. The air atmospheric air, the latter was so reduced in tube, its cold was 273 ' below zero, and it appeared in the form of drops like water. This product, which is called liquid or fluid air, has acid gas, bubbles eonstantly, and from its enormou cold emits a smoke or cloud like the top of a very high
mountain, and will only gradually resolve itself again into air when exposed to the ordinary atmosphere Fluid air costs about 10 marks (say $\$ 2.25$ ) for five cubic Professor Linde, of Munich. It produces the liquid for 10 pfennigs (say 21,4 cents) for five cubic meters, and it yields the product either as a gas or fluid, as one wishes. This is one of the most ingenious pieces of mechanisin recently known; its chief feature is its economy of pump has worked for a certain time, one turns a cock and the liquid air runs out at a ten

below zero:
In Professor Linde's method an air pump of five horse power condenses air to a pressure of 200 atmospheres chamber, causes down a spiral tube and is let out in on the outside of the spiral tube, bathing it and thu cooling the new air that has been pumped into the
tube to take its place. This cooled air follows on int the chamber, expands and again lowers its temper but as its temperature has become much lower, th but as its temperature has become much lower, the circulating process goes on, until the new air pumped perature of $273^{\circ}$ below zero, when it drops into the cooled, is made to refrigerate the newly pursped air more and more, until the necessary degree of cold

Another idea, which may or may not be an improve kept very low in temperature. Air in the cheap, portable form of a liquid rich in oxygen can be used for many pnrposes in manufactures
and the trades. The discovery of a cheap method may

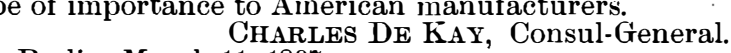
Berlin, March 11, 1897.

\section{BEES IN MEDICINE}

WhEREVER the bee has had a home honey has almost invariably been used both for food and medicine. From important part in the composition of many of the Egy, tian medical potions, and H. H. Sir Bhagvat Sinh . Jee,
M.D., has told us in his recently issued "History of Aryan Medicine," the role which honey took in the writers of the past who have alluded to its use may be mentioned Hippocrates and Galen. In the current issue of the St. Bartholome w's Hospital Journal Mr.
John Gutch gives some interesting gleanings from old John Gutch gives some interesting gleanings from old writers who have mentioned bees and honey in a thera-
peutic connection. Although honey has been used as not only the sweet product of the bee, but the bee itself has been used in therapeutics. According to the author of the article quoted above, bees drowned in
honey have been recommended for clearing the eyes, for staying vomiting, and as useful also for deafness. bound, for such is the violence of the medicine that he cannot otherwise patiently endure it. "The following remedy is given by Celsus: "The bodies of bees taken newly from the comb and powdered and drunk with
Dierretick wine powerfully cures dropsy."-Lancet.

* United States Consular Reporte.
Mechanics and Machinery.

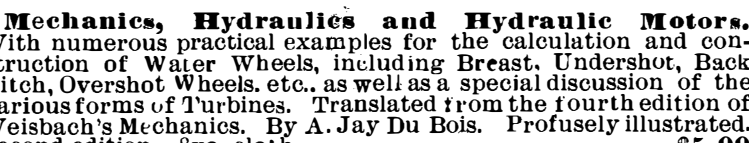

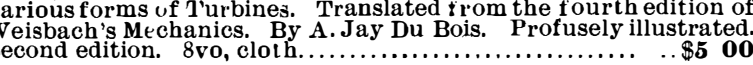

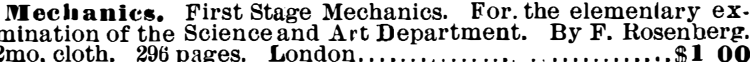
Mechanies. A Manual of Theoretical Mechanics. By Juliu
veisbach. Eighth American Edition. Translated from th Oourth German Edition, with an Introduction to the Calculus by
Eckley B. Coxe. 8vo, cloth. 1,100 pages. 902 illustrations. $\$ 10$ of

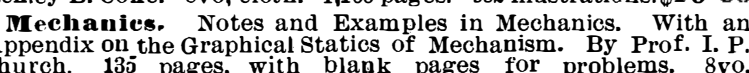
otb................................................... $\$ 2.00$
Mechanics. Nystrom's Pocketbook of Mechanics and Engi-

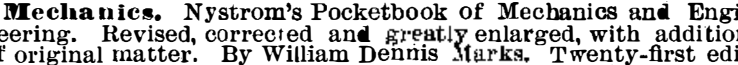

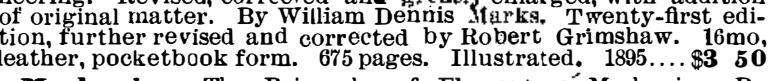

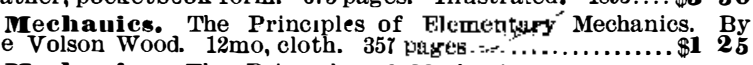

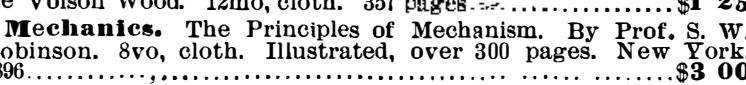
Meehanies. A Textbook of Elementary Mechanics for the
se of Colleges and Schools. By E. S. Dana. Twelfth edition.
mo, cloth............................................ \$1 50

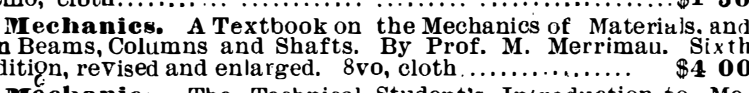
Mechanies. The Technical Student's Introduction to Me-
hanics. Being a series of papers showing the leading principles
f Physical Science exemplified in the properties ot bordies or my-

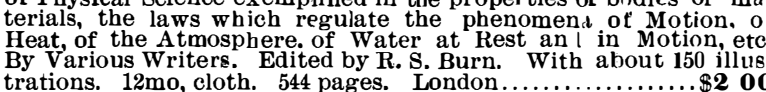
Mechanies. Theory of Steam Engine. Translated from
he fourth edition of Weisbach's Mechanies by A. Jay Du Bois.
Containing notes giving practical examples of Stati. nary, Marine ontaining notes giving practical examples of Stati. nary, Marine
nd Locomotive Engines showing American practice. By R. H. H.
Buel. Numerous illustrations. Second edition. 8vo, cioth..\$5 oO

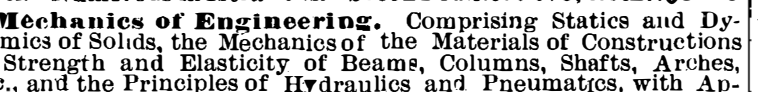

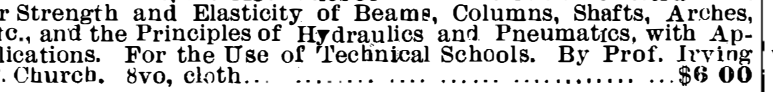

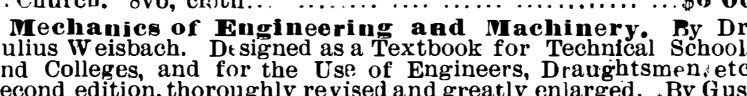

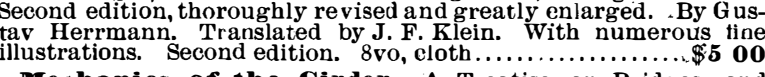
Mechanies of the Girder. A Treatise on Bridges and
Roofs, in which the necessary and sufficient weight of the
structure is calculated not assumed, and the number of Panels
and height of Girder that render the Bridge weight least for a

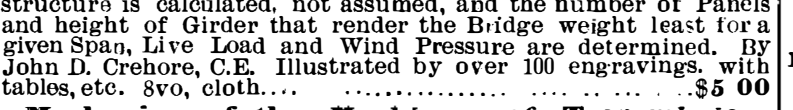

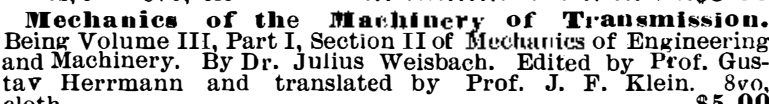

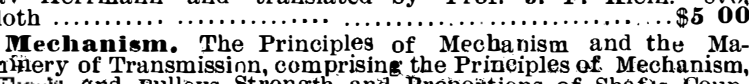

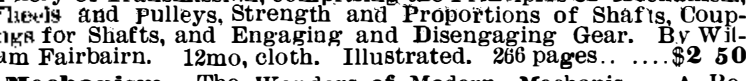

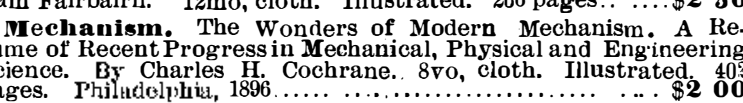
pages. Philudelphia, 1896................................ \$2 00
Milling Machine. A Mreatise on the Construction and Use
of Milling Machines as made by Brown \& Sharpe Manufacturing
Company. 8vo, cloth. 246 pages. Illustrated............... 51 50 Modern M Mechanism, Exhibiting the Latest Progress in
achines, Motors and the Transmission of Power. Being a sup-

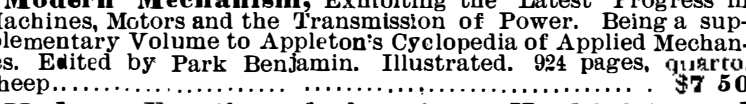

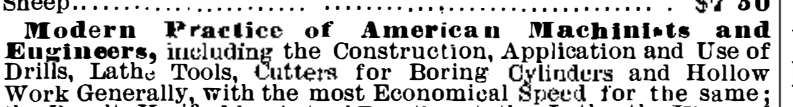

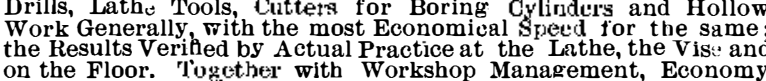

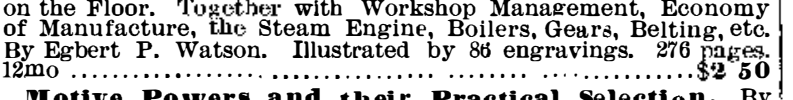
Motive Powers and the i P Practical Selection on B
Reginald Bolton. 12mo, cloth. 258 pages. London and New Movements. Five Hundred and Seven Mechanical Move-
ments, embracing all those which are most important in Dynam-
ics, Hydraulics, Hydrostatics, Pneumatics, Steam Engines, Mill
and other Gearing, Presses, Horology and Miscellaneous Ma-

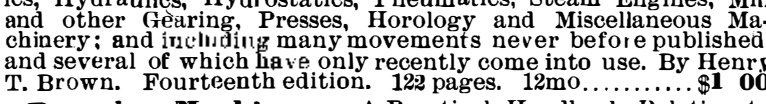
Pumpiug Wachinery. A Practical Handbook Relating to
the Construction and Management of Steam and Power Pumping
Machines. By William M. Burr. With upward of 270 engravings.
450 pages.

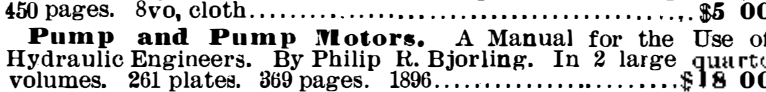

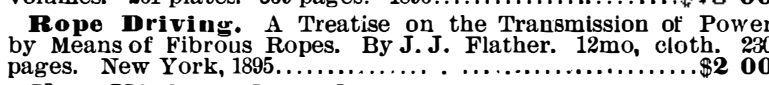

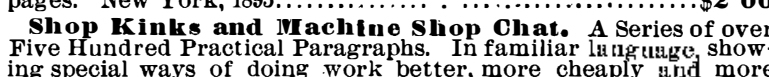

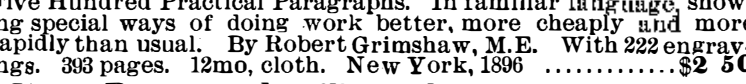

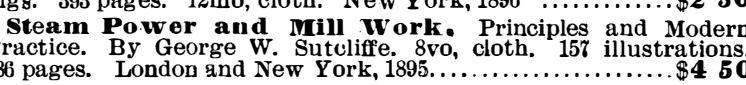

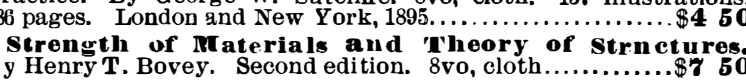
St resses. Pocketbook of Calculation in Stresses, etc., for
ngineers, Architects and General Use. By E. Monson George
mo, pocket size. 140 pages. London.... .................1 50

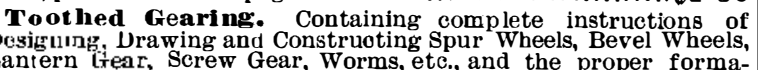

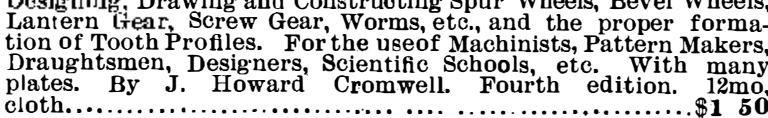

Our large Catalogue of American and Foreign Scientific and Technical Books, embracing more than Fifty different subjects, and containing 116 pages, will be mailed, free, to any address in the world.

Any of the foregoing Books mailed, on receipt of price, to any address. Remit by Draft, Postal Note, MUNN \& CO., 361 BroadWAY NEW YORK.
T

\section{Scientific American Supplement.}

\section{PUBLISHED WEEKLY.}

Terms of Subscription, $\$ \overline{5}$ a Year.

Sent by mail, postage prepaid. to subscribers in any
part of the United States or Canada. Six dollars a year. sent. prepaid, to any forejon country. All the back numbers of THE SUPPLEMENT, from the 10 cents each.

AH the back volumes of THE SuPPLEMENT can likewise be suppiiea. Two volumes are issued yearly.
Price of each volume, $\$ 2.50$ stitched in paper, or $\$ 3.50$ COMBINED RATES.-One copy of SCIENTIFIC AMIERICAN and one copy of SCIENTIFIC AMERICAN SUPPLiMENT, one year, postpaid. $\$ 7.00$.
A liberal discount to booksellers, news agents, and MUNN \& CO., Publishers, 361 Broadway, New Yorks, N. $\mathbf{Y}$

TABLE OF CON'TENTS.

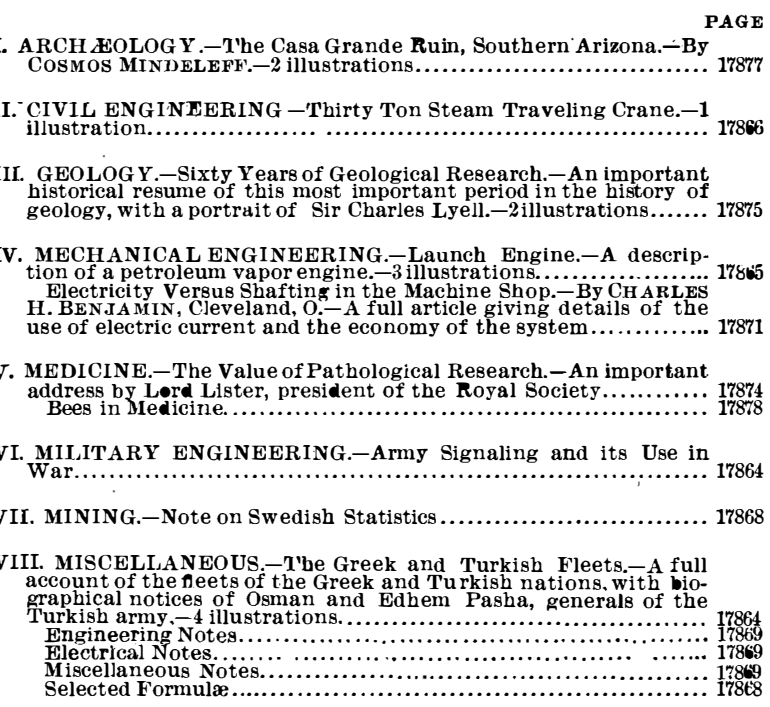

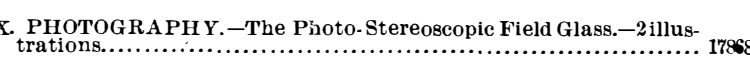

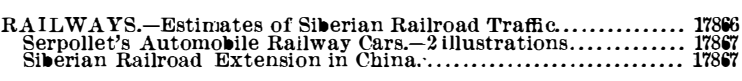
STEAM ENGINEERING.-Appairatus for Sending Water of
Condensation Automatically into Boilers.- 1 illustration........... 17865

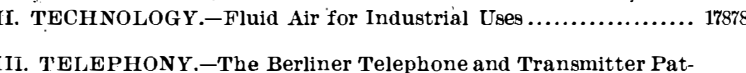

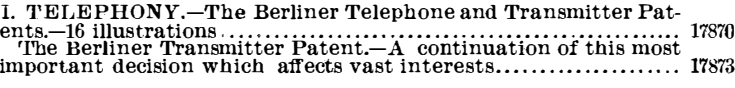

SPECIAL ANNIVERSARY NUMBER

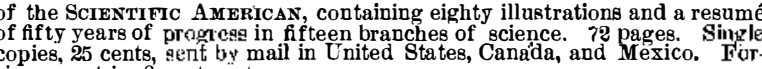

MUNN \& Co., 361 Broadway, New York.

\section{I897 Supplement}

\section{Catalogue Ready!}

The publishers of the Scientrific American announce that an entirely new 48 page SUPPLEMENT
Catalogue is now ready for distribution, and will be Catalogue is now ready for
sent free to all on application. IUUNN \& Co., Publishers, 36I Broadway, New York City.

\section{BUILDING EDITION} OF THE

SCIENTIFIC AMERICAN.

Those who contemplate building should not fail to

ONLY \$2.50 A YEAR.

Each number contains elevations and plans of a

COLORED PLATE.

MUNN \& Co., 361 Broadway, Now York.

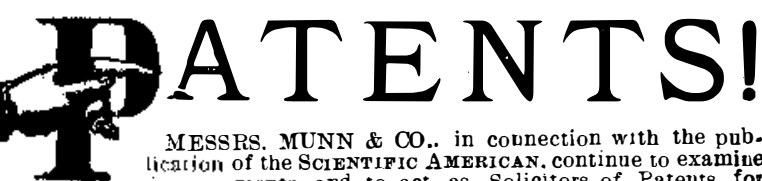

In this line e finvistiness they have had nearly fifty years' experience. and
now have unequaled faciitities for the prevaration of Patent Drawings,

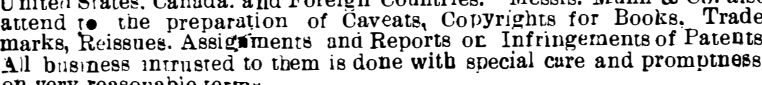

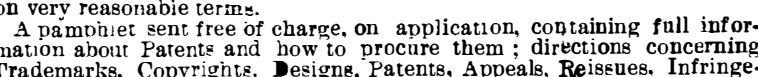

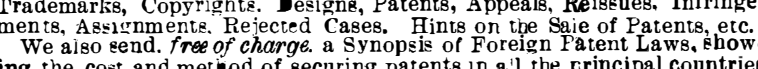
ing the cost and method of securing patents in a'l the crinci
of the worid. BRANCH OFFICES.-No. 622 and $624 \mathrm{~F}$ Street, Paciftc Building
near 7th Street. Washington, D.C. 